AWEJ for Translation \& Literary Studies, Volume 6, Number1. February 2022 DOI: http://dx.doi.org/10.24093/awejtls/vol6no1.4

Pp. 40-52

\title{
Race and Identity in Brit Bennett's The Vanishing Half
}

\author{
Rashad Mohammed Moqbel Al Areqi \\ English Department, Faculty of Sciences and Arts \\ Al Mandaq, Al Baha University, Al Baha, KSA, \\ Corresponding Author: alarikirashad2018@gmail.com
}

Received: 11/1/2021

Accepted: 1/26/2022

Published: $2 / 24 / 2022$

\begin{abstract}
Race and identity transformation have been overarching themes in the works of African American writers. Brit Bennett's The Vanishing Half (2020) is one fictional work that deals with identical twin sisters: Desiree and Stella Vignes. They are two light-skinned Black sisters who have chosen or rebuilt their identities based on the needs that allow them to live in peace among their communities. This study attempts to trace the importance of race and identity for the African Americans through exploring the lives of these twin sisters who leave their hometown. Through postcolonial critical concepts of identity and race, this research sheds light on the reasons behind the sisters' decisions to keep or shed their Black identity, as well as their community's influence on their decision to leave their hometown. This study found that the choices of race and identity the sisters made earlier in their lives identified their fate and established a path for their children. Desiree prefers to maintain her identity by marrying a Black man, and Stella sees her interest in marrying a White man and keeping her past hidden. Kennedy, Stella's daughter with a White man, and Jude, Desiree's daughter with a Black man, adhere to their parent's beliefs regarding race and identity. However, Stella and Desiree still long for their origin and home, and ultimately, they gather again at home they left together.
\end{abstract}

Keywords: Bennett, black, half, identity, race, vanishing, white

Cite as: Al Areqi, R. M. M. (2022). Race and Identity in Brit Bennett's The Vanishing Half. Arab World English Journal for Translation \& Literary Studies 6 (1) 40-52.

DOI: http://dx.doi.org/10.24093/awejtls/vol6no1.4 


\section{Introduction}

Race and identity are very important topics in African American writings. It does not bother the new generation of Black, but also it is an old issue argued by the first generation of Black writers, for instance, Toni Morrison, who dedicates her works to unraveling the reality of the African Americans' suffering and struggling through their lives, addresses race and identity in her novels. In her novels, The Bluest Eye, Beloved, and A Mercy, she has addressed many topics that engaged the Black people with the Whites. Such works unveil the reality of slavery in early America. This study addresses how the new generation of African Americans walk on the same path as the first generation, searching for their roots and identity, whatever the transformation that forced them to forget their race and identity, but eventually they find themselves yearning to their race and history.

This study examines how Bennett, as one of the new generation, takes the reader to the same concern of Black in general: race and identity. African Americans recognize well that their past is not written precisely so that the Black need to take the initiative to write about their long struggle to get freedom and rights. It is essential to realize the new generation's perspective on race and identity. Are there differences between the first generation and the second one regarding the writing of their past? Through this study, the readers may comprehend the reasons behind the Black's concern to bring light to their history and how they understand their race and identity.

Brit Bennett's The Vanishing Half recounts the transformation of the identities of identical twin sisters - Desiree and Stella Vignes - from Mallard, Louisiana. The founder of Mallard, Alphonse Decuir, established the town as a place for only light-skinned Black people, and he is proud of this achievement. At 16, the twins run away from Mallard to New Orleans. Shortly after that, Stella disappears without any indication about her destination, only that she wants to go her way. This study attempts to trace the transformation of the sisters' lives and how they reshape their identities and race to meet the demands of the communities they choose to be part of.

Bennett has divided the novel into six parts, focusing on the chronicling of the events: Part I: The Lost Twins, 1968; Part II: Maps, 1978; Part III: Heartlines, 1968; Part IV: The Stage Door 1982; Part V: Pacific Cove 1985-1988; Part VI: Places, 1986.

The narrative follows the second generation: the twins Desiree and Stella, as well as the third generation: their daughters Jude and Kennedy, who have been influenced by their mothers' earlier choices. The chronicle spans many decades, from the 1940s to the 1990s. The decision of the sisters undoubtedly determines their futures and their identities.

Identical twins are known to share the same genetic makeup and, therefore, are supposed to be closer in thoughts and decisions than fraternal siblings. As a result, the twins agree to run away together from Mallard to New Orleans because they cannot endure working as house cleaners. The irony is that they have not found a job in the new city besides working in a laundry. At the tender age of 16, they move on with their lives without looking back. Teenagers, in general, and Desiree and Stella, in particular, need a little freedom, with youth favoring to fulfill their ambitions away from their parents and the constraints of community. 
In other words, 16 is the age of rebellion against adults' charges and against the community's restrictions, which the twins see as a hindrance. Neither can imagine living at the mercy of adults, carrying out their orders without any objection; they only see the exhaustion in such orders. As an African American, Brit Bennett shows her concern for Black people as an extension of African past, which most African American writers use as rich material for their fiction. This is simultaneous recognition of their history to maintain identity and race as African Americans.

Bennett's Vanishing Half is one of the new novels issued in 2020 and race, and identity are one of the literary gaps that this study attempts to fill in. The previous studies about the topic discussed here and the writer are minimal, and this study will pay the reader's attention to such topics and stories. It is not an easy task to find references about the topic argued in this research.

\section{African-American Writings and Their Impact on American Literature}

The writings of African Americans began to get published in the second half of the eighteenth century, often focusing on equality and justice. For instance, Phillis Wheatley was enslaved in Boston dedicated her poems to morals and religious principles. Eighteenth-century authors were pioneers of African American literature, including Boston King and David George. English literature mentioned African characters only to perform specific roles in the theater, while in real life, their human rights neglected. Sidbury (2015) pointed out that:

Blacks could be found as princes, jesters, victims, heroes, criminals, slaves, and loyal retainers in English culture. Nonetheless, the complex of oppressive forces arrayed against the hundreds of thousands of Black people who actually lived in the British Empire blocked their access to literacy and the kinds of learning necessary to produce an accomplished writer. (p. 25)

African American authors represent a large part of American literature, contributing to different writings, in particular. African American writers introduce readers to race and identity by exposing their hidden history, focusing on slave resistance, racism and racialism, oppression, and color. They catch special attention to their heritage and history, which for a long time remains hidden. The word 'African' was used as a synonym for negro or Black. As Sidbury (2015) discussed:

Britons in England and America used the term "Africans" interchangeably with "Negroes" and "blacks" to refer to the people they purchased and imported into the Americas, as well as to the American-born (or creole) descendants of those victims of the slave trade. (p. 26)

African American history and its particularities started to appear in the late 1960s. Many African American writers addressed different issues concerning their communities in their writings, mostly fiction, and what they identified as obstacles in the way of freedom and progress. They focused on race, color, identity, immigration, oppression, injustice, slave resistance, and other milestones for Black development and stability. 
The slave narrative began to emerge, for example, in The Interesting Life of Olaudah Equiano, or Gustavus Vassa, the African (1789). At that time, Americans and political advocates supported the abolitionist movement. Those who had been enslaved wrote about the history of slavery, isolation, and discrimination, such as Fredrick Douglass's autobiography Narrative of the Life of Fredrick Douglass, which sold thousands of copies in a concise time. In addition, Harriet Jacobs published Incidents in the Life of a Slave Girl (1861) using a pen name to write about her experience as a slave and race-based abuse.

In the early twentieth century, after the American civil war ended, many important essays appeared, such as Booker T. Washington's Up from Slavery (1901) and W. E. B. Du Bois's The Souls of Black Folk (1903) established an African American literary canon. Later, Black writers became more recognized for fiction and poetry during the Harlem Renaissance, known as the New Negro Movement between 1917 and mid-1930. That was a period of African American revival. Many works of fiction, and poems, in particular, emerged, reflecting the awakening and consciousness of the African Americans from the likes of Langston Hughes and Jean Toomer. Many novels addressed racial discrimination, such as Ralph Ellison's Invisible Man (1952), narrated by an African American. In the 1970s, the voice of the African American emerged on the literary scene through Toni Morrison's literary works, including The Bluest Eye (1970), Sula (1973), and Song of Solomon (1977). In the 1980s, many other literary works were published, including Alice Walker's The Color Purple (1982), which won the Pulitzer Prize for Fiction, and Tony Morrison's Beloved (1987), which underscored the pains of slavery during the American Civil war.

In other words, African Americans recognized that no one could address their issues of rights and race other than the African American authors who had lived the traumatic experiences of exile and oppression. They went through a genuine reformation of their identities, relocating them to different cities. Loomba (2015) pointed out that:

The racial difference has functioned as one of the most powerful yet most fragile markers of human identity, difficult to police and maintain yet persistent, a constructed idea yet all too real in its devastating effects. Are human beings essentially the same or different? Is difference defined primarily by racial or cultural attributes? (p. 112)

Therefore, the literary history highlights the Black's ambitions and sufferings, as well as it raises global awareness of their issues of justice. Afro-American history has remained hidden and ignored in American institutions for a long time, and addressing the African American history of literature was a crime as deserved punishment. Racial stereotypes of African Americans began to weaken when the government took severe legal steps to guarantee African Americans' participation in the daily activities of life.

Black-centered movements started to appear, such as the civil rights movement, the Black Power movement, and the Black Arts Movement, which helped bring African American issues front and center. In addition, the American government passed many laws protecting African Americans' rights, facilitating their engagement in daily activities without racism. Furthermore, 
President Johnson passed the Civil Rights Act in 1964, which set in motion many of the laws ending segregation. Multiculturalism became a fact that was not easy to ignore.

On the other hand, many theorists expressed concern about postcolonial writings and theories, particularly African American literary works were marginalized and negligible. Discrimination against African American history and literature was institutionalized in the American literary canon, only taken into consideration if it reflected the concerns of Europe. Tyson (2015) stated: "... and included in the canon only when they reflect European literary tradition, that is, only when they resemble those European works already deemed 'great' for Eurocentrism is the belief that European culture is vastly superior to all others" (p. 378).

However, the worldview of race and African American writing changed and became tangible, and no one might ignore their efforts in fiction or other significant areas of life. Many contemporary authors have carved out a name for themselves and African American achievement in fiction, working hard to fictionalize their history and bring attention to their world of resistance and race. African Americans regraded themselves minorities and embarked on antiracist struggling in postwar Britain. Hall (2017) discussed how Black became a signifier of Black's identity.

the term "Black" became the signifier of an emergent identity that arose not from any basis in genetics, nor from shared customs, but from the discursive slide whereby conte sted meanings that gathered under the markers of cultural difference served to expand the ground on which political antagonism to the status quo was articulated.(p. 32)

Tony Morrison, who won the Nobel Prize for Literature in 1993, is one of these authors who made the world reconsider their views about African American writing and gained the trust of readers through the literary works of African American authors. In addition, many writers have contributed to the development of Afro-American novels, such as Tony Morrison, Alice Walker, Maya Angelou, John Edgar, and others. A new generation of African Americans, such as Percival Everett, Brit Bennett, Morgan Jerkins, and others, attempt to retrace the footsteps of the first African American novelists. All are working to correct the misrepresentation of the African American story and to stabilize the roots of the African American novel.

Hirsch (2018) addresses the issues of race and identity of Black and how the community realizes the blackness of African Americans or the Black in general. "the more I asserted my Black identity, the more of a threat I became to the prevailing order-that race is something unseen, unspoken of and unacknowledged in polite society" (p. 23,24). The first generation of African Americans lived their lives unseen and marginalized. They were not powerful enough to fight for their rights and freedom.

Brit Bennett focused on reclaiming African American fiction, which was marginalized for a long time but, more recently, has been playing more significant role in American literature in general. Bennett's debut novel, The Mothers (2016), was a New York Times bestseller, and also it received Hopwood and Hurston/Wright honors. Her second novel, The Vanishing Half (2020), was also a New York Times bestseller.

Arab World English Journal for Translation \& Literary Studies 


\section{Departure for a Different World and the Reasons for Leaving}

Twin sisters Desiree and Stella Vignes run away to find refuge from their work as cleaners, which they find consumes all of their effort and their energy. They are in search of better lives away from adult intervention or domination. They do not recognize how their decision would determine the course of their lives in the new communities they hoped to join or how their choice could affect their children's future: "Selfish girls running from responsibility. They wouldn't stay away long. City living would tire them out. They'd run out of money and gall and come sniffling back to their mother's porch. But they never returned again" (p. 9).

The twins took advantage of the Mallard Founders Day Picnic celebration to decide their future. Ultimately, they run away to New Orleans to start a new life that each twin envisioned separately. The irony is that Desiree was very excited to leave Mallard and start a new life. At the same time, Stella was hesitant initially, expressing no excitement or motivation to go home. However, when they settled in New Orleans, Stella disappeared without informing her sister about her destination or plans, "To Stella, leaving Mallard seemed as fantastical as flying to China. Technically possible, but that didn't mean that she could ever imagine herself doing it” (p. 12).

Stella and Desiree, even though they are twins, took different paths toward their imagined future. It was not only the physical effort and doing the laundry for the Duponts but also Mr. Dupont's attempt to corner Stella and sexually assault her that prompted Stella to agree to leave Mallard with her sister. When her sister wants her to go with her, she is not motivated to leave her home. Later on, after such physical and sexual violations at work, she agrees to go with her sister.

Desiree and Stella realize that if they remain in Mallard, they may not get an opportunity to complete their secondary studies. They could spend their lives in one low-paying job after another, which does not offer them dignified lives. They are also concerned with the shoddy work that may not help them in their future lives. The decision to leave is inevitable to get better opportunities in the future. Desiree and Stella shared traumatic experiences by Whites looking for any excuse to perpetrate evil acts against Black people.

White folks; kill you if you want too much, kill you if you want too little.' Willie Lee shook his head, packing tobacco into his pipe. 'You gotta follow they rules but they change 'em when they feel. Devilish, you ask me'. (p. 38)

Tragically, the sisters witnessed the savage murder of their father, Leon, by the hands of a White man who broke his fingers and shot him four times. Leon survived and taken to the hospital, but three days later, the White group found him and ended his life with two shots to the head. There was no reason to kill Leon, but the mob claimed that he sent a note to a White woman, even though he could not read or write: "He survived, and three days later, the white men burst into the hospital and stormed every room in the colored ward until they found him. This time, they shot him twice in the head, his cotton pillowcase blooming red" (p. 36). When the opportunity comes, the sisters decide to leave without a trace. 


\section{Identity Transformations and Race Appreciation}

Race means maintaining the physical, biological, and genetic particularities of human beings that distinguishes them from other groups. The idea of race classification comes from the colonizers, who insisted on maintaining such differences between ethnic groups to establish a hierarchy of superiority. Ashcroft et al. (2007) argued: "the notion of race assumes, firstly, that humanity is divided into unchanging natural types, recognizable by physical features that are transmitted through 'the blood' and permit a distinction to be made between pure and mixed races" (p. 198). Therefore, the colonizers' policies leave a gap between the Black and the White that assists the White to maintain their superiority and distinctiveness.

Each race endeavors to maintain its identity as loyalty to the ethnic group. The ethnic group sees in its race a symbol of their power and survival, appreciation and glorification of their roots. However, some individuals might not pay much attention to their race or find in their race signs of inferiority. These individuals might choose to distance themselves from their race when they have the opportunity, hoping for a better lifestyle and a better community that is more responsive to their needs. Such individuals might seek to escape from their people and race, even their identity, based on fleeting concerns. However, their nostalgia leads them back to their roots. Eventually, most of those who sought to escape their original identity and race return to the home where they share the same cultural and social background with their family and friends. It is not easy for most people who try to escape their identity and race to go ahead with their lives without considering memories.

Passing as White is a pressing need for some light-skinned Blacks; however, it is not an easy task; sometimes, a person's color, accent, or appearance uncovers the truth of their origin. The past and the race were hidden for a long time, but one day, the individuals will eventually expose themselves to embarrassing situations. Fate (2020), in his review of Bennett's The Vanishing Half, discussed this:

But if you're Black, no matter how light your skin, you'll always still be considered Black. That is unless you desire to walk on the side of life where privilege prevails - and you're able to "pass." Passing as White means you don't get followed around just because of your presumed race. It means your work choices are not limited to cooking and cleaning for White people —one step removed from slavery. (p. 39).

Stella and Desiree, two light-skinned sisters, have chosen their worlds, but their fates rely on their instant concerns. Desiree married Sam, a Black man and "The darkest man she could find" (p. 9). They have a daughter named Jude, closer to her father's color. Jude's classmates always bully her and call her names like "tar baby" and "blue skin." Despite ill-treatment of the community and discrimination, Jude does not think for a moment to forget her race or roots or to attempt to satisfy Whites by mimicking their lifestyle or accent.

Stella disappears within a year of arriving in New Orleans, leaving behind a note for her sister, revealing no plan. "Here was a note left behind in Stella's careful hand: Sorry, honey, but I've got to go my way" (p. 64). Unlike Desiree, Stella has worked on passing for White, taking 
advantage of her light Black color and hiding her past and race to assimilate into the White community. Stella watches TV and mimics the accents of Whites. Style of life assists her with moving into the White community without drawing attention to her race or roots, and Stella marries a White man with whom she has a daughter named Kennedy. Stella does not like to talk about her past, her family, friends, or the city she leaves. She always evades answering such questions or just ignores them.

"Where are you from, Mommy?" Kennedy asked her once during bath time. She was nearly four then and inquisitive. Stella, kneeling beside the tub, gently wiped her daughter's shoulders with a washcloth and glanced into those violet eyes, unsettling and beautiful, so unlike the eyes of anyone else she'd ever known.

"A little town down south," Stella said. "You won't have heard of it." She always spoke to Kennedy like this. (p. 145)

However, Stella passes smoothly into the White community, mimicking their customs and traditions. She has chosen her race and identity, which would give her peace and safety. She fabricates lies about her race and past, even with her husband and, later on, with her daughter. Stella appears White, based on traits inherited from her father, but she spends her life on the edge, fearing someone from her past might recognize her and uncover her secret, turning her and her daughter's lives upside down.

\section{Stella and Desiree's Lives After Marriage and Their Children}

Desiree's marriage ends because of her husband's abuse. Desiree could not endure her husband's repeated physical attacks: "She'd told him about all the ways Sam had hurt her: slamming her face into the door, dragging her by her hair across the bathroom floor, backhanding her mouth, his hand streaked with lipstick and blood" (p. 96). Such repeated violence impacts Desiree's life, and she does not like that her daughter sees such violence. Ultimately, Desiree runs away with her little daughter Jude to Mallard, the home she once left. She thought living with someone of her race would bring her happiness, but in fact, she does not find that peace in her marriage. In the beginning, she tries to find excuses for her husband's behavior, that he is disappointed because of Martin Luther King, Jr.'s assassination or that he desires another baby. However, her excuses do not help her any longer, as her husband's repeated mistreatment does not allow her an opportunity to reconsider leaving him.

She does not consider any other place than Mallard to spend life with her daughter, only her childhood home, which symbolizes refuge and security during hard times. The same house once was a source of inconvenience that she left voluntarily. She recognizes well that she belongs to that place and those people, sharing with them good and bad times.

Desiree's marriage could not provide her with the peace and safety she sought or dreamed of and, therefore, was not a success. She chose to come back home to raise her daughter, away from her husband's violence. Jude eventually goes to college at UCLA. A dark-skinned girl raised among light-skinned Black people. Jude was mistreated by the White because of the dark skin she

Arab World English Journal for Translation \& Literary Studies 
inherited from her father. Jude develops a connection with a boy who is also from the South, Reese, who is transgender. She helps him finance surgery for his chest.

Stella has married her boss, a White man named Blake Sanders, and they embark on a new life. He is wealthy, and they have a beautiful daughter named Kennedy, who has blond hair and violet eyes. Kennedy has inherited her father's attributes. "The newborn in her arms was perfect: milky skin, wavy blonde hair, and eyes so blue they looked violet. Still, sometimes, Kennedy felt like a daughter who belonged to someone else, a child Stella was borrowing while she loaned a life that never should have been hers" (p. 145).

Stella lives with a different identity and hides her past from her husband. She lives a happy life, as she keeps her secrets to herself. The irony is that a Black family, Reginald and Loretta Walker and their daughter Cindy, move into the same neighborhood, and Stella treats them as a Black family, ignoring her race and roots. When Stella's daughter, Kennedy calls their daughter Cindy the n-word, the Walkers leave.

You know what she said to Cindy? Well, the girls were playing some game and Kennedy was losing so she said, 'I don't want to play with a nigger.'” Her stomach sank. "Loretta, I-" "No, I understand," Loretta said. "I don't blame her. It all comes from the home, see. And like a fool, I let you into mine. (p. 190)

The twins have chosen their fate according to their expectations. Their children lead different lives. Jude applies for medical school and has met Kennedy, pursuing acting. Jude recognizes Stella and later tells Kennedy about her mother's history when she acknowledges the resemblance with her mother.

\section{Belonging to Race through Different Generations}

Despite the sisters deciding on different lives, they have faith in belonging to a race and home. First, Desiree's choice to return to Mallard after being abused by her husband is a sign of her strong sense of belonging to a place and people, and she prefers raising her daughter among her people. Running away from home at 16 was an escape from the challenging work as a maid, and later she worked as a fingerprint analyst in Washington, DC, after leaving New Orleans, and then as a waitress at the diner in Mallard. She eventually recognizes that she shares a culture and social background with the people and town of Mallard.

Desiree is tolerant of her husband's abuse initially; however, when she realizes that the violence will affect her daughter's future life, that her daughter can see the physical abuse in the bruises on her face, she decides to leave him. Desiree likes spending her life with someone closer to her race and traditions, but this does not give her an excuse to endure his frequent abuse. Jude has suffered from harsh discrimination at school because of her dark color. However, she does not deny her race or identity to appease the community.

I don't have any girlfriends, really." "Why not?" "I don't know. I never really had any growing up. It's the place I come from. They don't like people like me." "Blacks, you 
mean." "Dark ones," she said. "The light ones are fine." Kennedy laughed. "Well, that's silly." (p. 228)

Jude proves herself by studying and attending medical school. She does not depreciate her race or origin. On the contrary, she works toward a medical degree to prove to her community that the superiority is in her academic performance, not in her color. Being bullied by her classmates may not affect her progress in life, but it motivates to prove herself academically. She is supportive of Reese, helping him finance surgery for his chest and maintaining a close connection with him. Like her mother, Jude lives peacefully in the White community.

On the other hand, Stella struggles to hide her past and race from her White husband and daughter, despite repeated questions from Kennedy about her family and friends. Kennedy does not find satisfactory answers because Stella always ignores her questions or escapes direct answers. Stella knows that uncovering her past and race will put an end to her life with her husband, and she does not want to lose the peace and security she feels in her new world. When Jude points out Stella's resemblance to her mother, Desiree, her twin sister, Stella strives to deny any connection for fear of losing the happy life chosen by herself. However, she does not resist the desire to visit Desiree in Mallard or hesitate to gift her expensive wedding ring to support her mother's failing health, Adele. The reader realizes that Stella still cares about her relatives and belonging to her race and home.

Stella and Kennedy have different identities and try to indicate their superiority to Blacks, even though they are, in reality, one of them. In the beginning, Stella does not like to see a Black family in her district because it reminds her of her origin, and their existence in the community may raise many questions about Stella's color. She presents herself to Loretta as a White descendant, while Loretta represents Blacks. Kennedy also degrades Cindy by calling her names like the n-word to indicate the inferiority of the Black family.

Eventually, Kennedy develops a relationship with a physics professor, Frantz. He is the first Black man she dates, and finally, she moves in with him. Her relationship with a black man is a sign that Kennedy is beginning to accept her origins, as she does not find any problem with dating a Black man. The race marks the lives of Stella and her daughter, and Kennedy's continued connection with Jude is evidence of her desire to belong to her race and her people. Ultimately, Stella tells her daughter the truth after Jude gives Kennedy a photo of both of their mothers with the rest of the family in Mallard. Stella does not lie when Kennedy asks her about her wedding ring, but she does not want her daughter telling the truth of their race and origin to Blake.

Stella has attained a perfect position in the community, becoming an adjunct professor of statistics at Santa Monica College. After Loretta left the neighborhood, Stella felt lonely, and her husband encouraged her to work. "Sometimes being a twin had felt like living with another version of yourself. That person existed for everyone, probably, an alternative self that lived only in mind" (p. 222). Stella has lost her friendship with Loretta and she spends her time thinking of her sister, the vanishing half.

Arab World English Journal for Translation \& Literary Studies 


\section{Returning Home and Symbolism}

Desiree reconsiders returning home early, after her husband's abuse, as she is confident he will not change his behavior. She returns to Mallard to live with her people and her family, and it becomes the best place to raise her daughter. Stella, meanwhile, spends her time resisting her feelings to return. Desiree wants to forget anything that reminds her of her past, but in the end, she cannot ignore her race or her people. Stella decides to visit Desiree and requests forgiveness for denying their past. Stella attempts to maintain her family and her husband in a community that does not consider Blacks. When she took work as a secretary in New Orleans, she knew that only a White would hire someone from his race. Her color enabled her to get the job that would change her future.

Bennett addresses the feeling of abandonment each twin has concerning their other half. Each twin feels there something is missing as they disappear to find their path in life. The title does not mean that each disappears but that everyone vanishes into another community. Desiree marries a Black man, who does not resemble her light color. The people of Mallard try to keep the community's color, light-skinned, with each new generation becoming lighter and lighter. Mallard's founder wanted a town of visible and respectable light-skinned people, and marrying dark-skinned Blacks was not encouraged. Desiree goes against these rules by marrying a darkskinned Black man. Meanwhile, Stella's daughter is blond with violet eyes from her marriage to a White man.

Eventually, Bennett brings Stella and Desiree home to indicate that it is not easy to leave behind your race or identity. It runs in the blood, and willful forgetfulness cannot continue forever. Humans naturally long for their roots and motherland. Undoubtedly, Stella does not resist at the end, coming home to find her vanished second half, which she is afraid of losing forever.

Their abandonment was forced by hard times and immediate circumstances. Still, the gathering in Mallard symbolizes the twins coming back to their roots and identity, despite the decisions they have already made in their lives. The new generation, represented by Kennedy and Jude, longs for their home. Adele passes away, and there is a continuous transformation in the lives of the twin sisters, from light-skinned Black to White. The impact of the past shaped the future decisions of Stella and Desiree.

Bennett ends the narrative with Jude slipping out the back door with her boyfriend and running through the woods toward the river at sunset. And, going back to nature, to the motherland with the sun about to vanish from the sky. It symbolizes leaving their past and troubles behind with the sun's setting. They dive into the cold water as a sort of cleansing and purification for past sins; sins will disappear to settle at the bottom of the river. In addition, the complexities of race and gender will drift away with the current. Life will continue on its course like the river, and the power of nature will lead everyone to a new stage of their lives. The river's course is unstoppable, symbolizing life and regeneration, flowing to its destination, out of human control. "This river, like all rivers, remembered its course. They floated under the leafy canopy of trees, begging to forget" (p. 329). 
There are opportunities for further research of both the narrative and the author. A hybrid examination of the younger generation and transgender identity may be a rich area for further study. In addition, the use of a psychoanalytic approach to probe deeply into the psychological aspects behind the twins' escape and their traumatic experiences would be helpful. In particular, Stella's attempt to hide her past, and her fear of her husband recognizing her race and roots, in addition to the physical violence and sexual harassment they experience in their hometown. This paper only focused on the transformation of the twins' identity and the reasons/realities behind their journey to home. Belonging to their home is a fact that cannot be forgotten or ignored.

\section{Conclusion}

Although Desiree and Stella decide their race and identity, each missed their second half. Both go against the laws of their community and the rules of the race. Desiree marries Sam, a Black man, "the darkest one she could find." However, her marriage is getting worse day by day because of her husband's abuse that leaves bruises on her face and scars on her body. Desiree decides to return to Mallard, a safe refuge for her and her little daughter. Desiree has already violated Mallard's race rules by marrying a dark man instead of a light-skinned man to maintain the community's lighter color. Thus, her daughter Jude is called names like "blue skin" or "Black tar" by her classmates at school. Stella, on the other hand, makes use of her fair skin and applies for a job specified for Whites only. She wins the position, but, in turn, she must leave her past behind. Stella attempts to forget her family, friends, race, and light-skinned identity. She enjoys marrying a White man who brings happiness and security to her life. Eventually, Stella could not continue in life without thinking about Desiree, her second half. She could not continue to conceal her past, especially when confronted by Jude, who reminds her of her past. She did not inform her sister about her destination or her intentions. She wanted to pass and assimilate into the White society without any trace of inconvenience, and Stella was able to enjoy herself for a while. Stella also went against the conventions of race by choosing to assume another identity that guaranteed an honorable life. By doing so, she hides her past, her relatives and lives in fear of exposing her story. This study found that the pull of race and blood drives Desiree and Stella, as well as their daughters' desire to return home for a family reunion that became an undeniable fact. The twins' family reunion is a sign of belonging to their place and their people, despite the identities they have already assumed and the circumstances that forced them to abandon their identity in the first place. Ultimately, Kennedy accepts her friendship with Jude as both a Black girl and one of her relatives. Her relationship with a Black man is also an indicator of Kennedy's yearning for her roots and race. However, Kennedy finally ends her relationship with the Black man and returns to Los Angeles.

\section{About the Author:}

Rashad Mohammed Moqbel Al Areqi is an associate Prof. of English Literature at Al Baha University. He got his PhD. Degree in English Literature in 2008, Putra University, Malaysia. He studied an intensive course in Contemporary American Literature, University of Louisville, Kentucky, USA. Recently, Dr. Rashad is teaching Literature courses at Al-Baha University. He has published many articles in international journals. ORCID ID: https://orcid.org/0000-00023055-7104

Arab World English Journal for Translation \& Literary Studies 
AWEJ for Translation \& Literary Studies Volume, 6 Number 1. February 2022

\section{References}

Ashcroft, B., Griffiths, G., \& Tiffin, H (2007). Post-Colonial Studies: The Key Concepts ( $2^{\text {nd }}$ ed.). London and New York: Routledge.

Baker, Jr. H., \& Simmons, K. (Eds.) (2015). The Trouble with Post-Blackness. New York: Columbia University Press.

Bennett, B. (2020). The Vanishing Half. New York: Riverhead Books.

Buschendorf, C. (Ed.) (2018). Power Relations in Black Lives. Transcript Verlag, Bielefeld, USA.

Fain, K. (2015). Colson Whitehead: The Postracial Voice of Contemporary Literature. Lanham, MD: Rowman \& Littlefield.

Gray, Richard. (2015). A Brief History of American Literature. Wiley-Blackwell. The USA. Hall, Stuart. (2017). The Fateful Triangle: Race, Ethnicity, Nation. Harvard University Press. USA.

Hirsch, Afuna. (2018). BRIT(ish) on Race, Identity, and Belonging. Penguin Random House, Uk. Jarrett, G. (2013). A Companion to African American Literature. Hoboken, NJ: Wiley-Blackwell. Lazarus, N. (2004). The Cambridge Companion to Postcolonial Literary Studies. Cambridge: Cambridge University Press.

Loomba, A. (2015), Colonialism/Postcolonialism ( $3^{\text {rd }}$ ed.) New York: Routledge.

Morley, C. (2012). Modern American Literature. Edinburgh: Edinburgh University Press.

Patton, K. (2020). The Vanishing Half: A Novel (Review). Christian Century, Riverhead. https://www.christiancentury.org/katara-patton

Sidbury, J. (2015). Africa in Early African American Literature. New York: Routledge. Taylor, P.C. (2007). Post-Black, Old Black. African American Review, 41, (4), 626-640. Tyson, L. (2015). Critical Theory Today ( $3^{\text {rd }}$ ed.). New York: Routledge.

Young, R. (2003). Post-colonialism: A Very Short Introduction. New York: Oxford University Press. 